\title{
PENATAAN KAWASAN WISATA PANTAI GESING KECAMATAN PANGGANG, KABUPATEN GUNUNGKIDUL, YOGYAKARTA
}

\author{
Hana Grace Yosephine ${ }^{1)}$, Irwan Wipranata ${ }^{2}$, Sylvie Wirawati ${ }^{3)}$ \\ 1)Program Studi S1 PWK, Fakultas Teknik, Universitas Tarumanagara, hannagy36@gmail.com \\ 2)Program Studi S1 PWK, Fakultas Teknik, Universitas Tarumanagara, irwan_wipranata@yahoo.co.uk \\ 2)Program Studi S1 PWK, Fakultas Teknik, Universitas Tarumanagara, sylview@ft.untar.ac.id
}

Masuk: 06-08-2021, revisi: 25-08-2021, diterima untuk diterbitkan: 23-10-2021

\begin{abstract}
Abstrak
Kawasan wisata Pantai Gesing merupakan salah satu destinasi wisata yang berada di Kabupaten Gunungkidul dan dikelolah oleh Dinas Pariwisata Kabupaten Gunungkidul. Kawasan wisata Pantai Gesing diresmikan pada tahun 2017, Pantai Gesing adalah pantai dengan bentuk bentang alam berupa pantai pasir putih, bukit dan pantai kawasan wisata ini memiliki keunikan pada ombak yang kecil dan pasir pantai yang halus serta berwarna krem terang. Kondisi eksisting dari Kawasan Wisata Pantai Gesing yang memiliki pemandangan alam dan kondisi alam yang baik, serta keunikan tersendiri. Namun, potensi yang tersedia belum dapat dimanfaatkan secara optimal karena belum memiliki fasilitas, sarana dan prasarana yang mendukung kegiatan dan potensi yang ada. Selain itu, pengelola kawasan wisata Pantai Gesing belum melakukan promosi untuk kawasn wisata ini sehingga masih banyak pengunjung yang tidak mengetahui kawsan wisata ini, selain itu minimnya informasi semakin membuat kawasan wisata ini tidak banyak diketahui pengunjung. Kawasan wisata Pantai Gesing masih belum memiliki fasilitas, sarana dan prasarana yang memadai seperti tempat sampah, gazebo, kios souvenir, guest house, rambu petunjuk arah, lampu jalan, jaringan telekomunikasi, air bersih dll sehingga kawasan wisata Pantai Gesing memerlukan penataan untuk menata dan memperbaiki fasilitas yang telah ada, membangun fasilitas serta sarana dan prasarana yang dibutuhkan.
\end{abstract}

\section{Kata kunci: Fasilitas; Sarana dan Prasarana; Promosi; penataan Pantai}

\begin{abstract}
The Gesing Beach tourist area is one of the tourist destinations in Gunungkidul Regency and is managed by the Gunungkidul Regency Tourism Office. The Gesing Beach tourist area was inaugurated in 2017, Gesing Beach is a beach with a landscape shape in the form of white sand beaches, hills and beaches. This tourist area is unique in its small waves and soft and light cream colored beach sand. The existing condition of the Gesing Beach Tourism Area which has natural scenery and good natural conditions, as well as its own uniqueness. However, the available potential cannot be utilized optimally because it does not yet have the facilities, facilities and infrastructure that support existing activities and potentials. In addition, the manager of the Gesing Beach tourist area has not promoted this tourist area so that there are still many visitors who do not know this tourist area, besides the lack of information makes this tourist area not widely known to people. The Gesing Beach tourist area still does not have adequate facilities, facilities and infrastructure such as trash cans, gazebos, souvenir shops, guest houses, directional signs, street lights, telecommunications networks, clean water, etc. existing facilities, build the required facilities and infrastructure.
\end{abstract}

Keywords: Facilities; Facilities and Infrastructure; Promotion; Coastal Planning 


\section{PENDAHULUAN}

\section{Latar Belakang}

Kabupaten Gunungkidul yang memiliki banyak kawasan wisata seperti pantai, goa dll. Kabupaten Gunungkidul sendiri memiliki luas wilayah sebesar $1.485 \mathrm{~km} 2$ dengan letak geografis $7^{0} .46^{\prime}-8^{0} .12^{\prime}$ Lntang Selatan dan $110^{\circ} .21^{\prime}-110^{\circ} .50^{\prime}$ Bujur Timur. Pusat Pemerintahan Kabupaten Gunungkidul berada pada Kota Wonosari dengan kecamatan sebanyak 18 dan 144 desa. Kabupaten Gunungkidul memiliki beragam jenis pariwisata alam seperti pantai goa, bukit, air terjun, dll. Pantai Gesing adalah salah satu dari wisata pantai yang dimiliki oleh kabupaten ini.

Pantai Gesing adalah pantai dengan bentuk bentang alam berupa pantai pasir putih, bukit dan pantai karang yang dikelola oleh Dinas Pariwisata dan Pokdarwis. Saat berkunjung ke Pantai Gesing wisatawan akan disuguhkan dengan pemandangan yang indah, pantai ini sendiri memiliki keunikan pada ombak lautnya dikarenakan Pantai Gesing adalah pantai yang memiliki ombak yang kecil sehingga wisatawan dapat bermain air maupun berenang di sekitarnya, Kawasan wisata Pantai Gesing juga memiliki pasir pantai yang halus dan berwarna krem muda. Selain itu, terdapat pemandangan yang indah dari atas tebing pantai serta terdapat keanekaragaman hasil laut yang dapat dinikmati di rumah makan sekitar pantai ini atau para wisatawan dapat menangkap sendiri hasil laut dari pantai ini.

Pengunjung Pantai Gesing tidak hanya anak-anak muda namun banyak juga pengunjung yang datang bersama keluarganya untuk berlibur di pantai ini, Pantai Gesing juga dikenal sebagai pantai nelayan karena mayoritas penduduknya bekerja sebagai nelayan di pantai ini. Para nelayan menjual hasil tangkapannya ke tempat pelelangan ikan (TPI) atau bisa menikmati hasil laut yang sudah diolah. Para pengunjung diperbolehkan untuk memancing namun harus membawa alat pancing sendiri, serta dapat membeli hasil laut yang sudah diolah di tempat makan yang terdapat di Pantai Gesing. Namun pengelola kawasan wisata Pantai Gesing belum melakukan promosi untuk kawasn wisata ini sehingga masih banyak pengunjung yang tidak mengetahui kawsan wisata ini, selain itu minimnya informasi semakit membuat kawasan wisata ini tidak banyak diketahui orang-orng.

Kawasan wisata Pantai Gesing masih belum memiliki fasilitas, sarana dan prasarana yang memadai seperti tempat sampah, gazebo, kios souvenir, guest house, rambu petunjuk arah, lampu jalan, jaringan telekomunikasi, air bersih dll. Selain itu fasilitas yang sudah ada masih belum tertata, kurangnya tempat sampah juga membuat banyaknya sampah di pantai juga di sekitar perahu nelayan. Tidak tersedianya jaringan telekomunikasi dan transportasi umum juga membuat pengunjung dan pedagang mengalami kesulitan dalam berkomunikasi dan juga menjadi hambatan bagi para pengunjung jika ingin memesan kendaraan online yang disebabkan tidak adanya transportasi umum yang bisa digunakan oleh pengunjung untuk berpindah tempat. Kawasan wisata Pantai Gesing masih belum terdapat guest house sehingga para pengunjung tidak dapat bermalam di sekitar kawasan wisata Pantai Gesing sehingga kawasan wisata Pantai Gesing memerlukan penataan untuk menata dan memperbaiki fasilitas yang telah ada, membangun fasilitas serta sarana dan prasarana yang dibutuhkan.

\section{Rumusan Permasalahan}

Rumusan masalah pada penelitian ini adalah kurangnya informasi dan promosi dari kawasan wisata Pantai Gesing sehingga tidak banyak pengunjung yang berkunjung. Selain itu dengan kurangnya fasilitas, sarana dan prasarana yang dapat mendukung kawasan membuat para pengunjung mengalami hambatan dalam menuju kawasan wisata sehingga potensi yang dimiliki kurang dapat menarik pengunjung, serta kurang tertatanya fasilitas yang sudah ada. 


\section{Tujuan}

Adapun tujuan penelitian ini adalah untuk mengusulkan penambahan fasilitas, sarana dan prasarana yang dibutuhkan oleh kawasan wsata Pantai Gesing dan melakukan penataan fasilitas yang sudah dimiliki, mengusulkan masterplan yang penataan kawasan wisata Pantai gesing yang dapat meningkatkan informasi dan tempt yang dapat digunakn untuk melakukan event atau promosi di kawasan wisata Pantai Gesing.

\section{KAJIAN LITERATUR}

\section{Pariwisata dan Wisata Pantai}

Pariwisata merupakan suatu kegiatan wisata yang kegiatannya ditunjang dengan berbagai fasilitas, baik fasilitas yang akan diberikan oleh masyarakat ataupunfasilitas yang diberi oleh pngusaha dan pemerintah. Berdasarkan Undang-Undang No.10 Tahun 2009 tentang kepariwisataan, mengatakan bahwa kepariwisataan dapat dikatakan sebagai kegiatan yang berkaitan dengan pariwisata dan dianggap sebagai suatu kebutuhan setiap orang yang melakukan interaksi antara wisatawan dan masyarakat setempat.

Pariwisata diketahui memiliki komponen penunjang yang harus ada didalam lokasi wisata. Menurut (Buhalis, 2001) melalui teorinya komponen pariwisata terdiri dari 6A yaitu Attraction, Accessibility, Activity, Amenities, Accomodation, dan Ancillary.

a. Attraction adalah segala hal yang mampu menarik minat para wisatawan untuk dapat menyempatkan diri berkunjung ke kawasan wisata atau secara khusus ingin dating untuk berwisata

b. Accessibility (Akses) merupakan komponen yang penting dalam mempermudah akses menuju tempat wisata. Selain itu, accessibility juga merupakan tingkat intensitas suatu daerah tujuan wisata atau destinasi wisata dapat dijangkau oleh wisatawan (Sugiama, 2011).

c. Activities (aktivitas) adalah kegiatan yang dapat dilakukan di destinasi yang dapat memberikan pengalaman bagi wisatawan.

d. Amenities (Fasilitas Pendukung) adalah kelengkapan berbagai fasilitas yang sangat dibutuhkan di destinasi wisata.

e. Accommodation (Penginapan) diartikan sebagai tempat tinggal sementara di lokasi tujuan wisata yang tentunya di satu destinasi dengan destinasi lainnya pasti berbeda.

f. Ancillary Services adalah organisasi pengelola destinasi wisata. Organisasi pemerintah, asosiasi kepariwisataan, tour operator dan lain-lain.

Berdasarkan Peraturan Daerah Gunungkidul no.74 tahun 2018 tentang rencana pembangunan kawasan perdesaan agropolitan, wisata alam minat khusus dan wisata pantai, bahwa kawasan wisata pantai adalah kawasan pantai yang telah tumbuh dan sedang berkembang, serta dapat memacu berkembangnya sistem usaha wisata yang dapat melayani dan mendorong kegiatan pembangunan suatu kawasan wisata pantai.

\section{Wisatawan dan Karakteristik wisatawan}

Wisatawan memiliki banyak pengertian salah satunya Menurut Forum Internasional (1937) mengatakan bahwa wisatawan adalah seseorang yang melakukan suatu perjalanan dalam waktu perjalanan selama 24 jam atau lebih baik melakukan perjalanan di dalam negeri maupun luar. Wisatawan memilik karakteristik sosial ekonomi dan karakteristik berdasarkan pola kunjungan. karakteristik sosial ekonomi terdiri dari Jenis kelamin, Usia, Asal daerah, Status perkerjaan dan Pendapatan perbulan. Sedangkan karakteristik berdasarkan pola kunjungan terdiri dari Tujuan kunjungan, Frekuensi kunjungan, Teman perjalanan Alat transportasi,Lama waktu kunjungan, Waktu kunjungan dan Besar pengeluaran selama berkunjung. 


\section{Sarana, Prasarana dan fasilitas}

Sarana pariwisata, Menurut Lothar A. Kreck (1996:197) sarana kepariwisataan dapat dibagi menjadi tiga bagian, yakni :

a. Sarana pokok kepariwisataan merupakan pihak yang melakukan kegiatan usaha di lokasi pariwisata dan memiliki ketergantungan pada kunjungan dari para wisatawan.

b. Sarana pelengkap kpariwisataan merupakan pihak-pihak atau dapat berupa tempat yang menyiapkan fasilitas untuk tujuan rekreasi dan berfungsi untuk melengkapi sarana pokok dari lokasi pariwisata tersebut.

c. Sarana penunjang kepariwisatan merupakan sebuah perusahaan yang memiliki peran sebagi penunjang sarana pelengkap dan sarana pokok dari pariwisata.

Prasarana pariwisata, menurut (Suwantoro, 2004) merupakan suatu sumber daya alam dan sumberdaya manusia yang sangat dibutuhkan oleh wisatawan dalam perjalanannya di daerah wisata yang dituju. Sedangkan prasarana pariwisata, menurut (Inskeep, 1991) adalah suatu prasarana wisata dibutuhkan untuk melayani para wisatawan yang sedang melakukan sebuah perjalanan wisata. Prasarana terdiri menjadi :

a. Prasarana Akomodasi : merupakan suatu prasarana utama yang sangat penting dalam pariwisata alam. Pengeluaran terbesar dari seorang wisatawan terletak pada prasarana akomodasi

b. Prasarana Pendukung : Prasarana pendukung merupakan prasarana yang harus terletak dilokasi yang mudah ditempuh oleh para wisatawan-wisatawan.

\section{Penataan Kawasan Wisata Pantai}

Penataan kawasan dimaksudkan sebagai suatu pengelolaan terpadu yang bertujuan untuk mengkordinasikan dan mengarahkan berbagai aktivitas dari dua atau lebih sebuah sektor dalam perencanaan pembangunan yang erat kaitannya dengan penataan wilayah pantai. Penataan kawasan wisata pantai pada umumnya bertujuan sebagai suatu usaha secara terprogram yang dapat mengharmoniskan dan mengoptimalkan antara kepentingan untuk memelihara lingkungan khususnya kawasan pantai, keterlibatan masyarakat dan pembangunan ekonomi.

\section{Masterplan}

Masaterplan merupakan sebuah rencana tindak yang komprehensif atau yang jauh jangkauannya, rencana ini di bentuk dari serangkaian keputusan yang disusun oleh satu orang atau tim mengenai bagaimana melakukan sesuatu di masa depan. Rencana induk atau rencana pembangunan atau rencana kota dapat didefinisikan sebagai rencana umum mengenai tata kota di masa depan yang menunjukkan jalan eksisting dan jalan yang diusulkan, ruang terbuka, bangunan umum, dll, selain itu masterplan juga merupakan dokumen perencanaan jangka panjang yang menyediakan tata letak konseptual untuk memandu pertumbuhan dan perkembangan di masa depan.

\section{METODE}

Dalam pengerjaan penelitian ini terdapat empat metode pengumpulan data yang digunakan yaitu observasi lapangan, keusioner, dokumentasi dan studi literature. Untuk metode analisis menggunakan metode kualitatif untuk mengetahui kondisi dan daya Tarik di kawasan wisata Pantai Gesing, metode kuantitatif digunakan untuk mengetahui kebutuhan ruang yang diperlukan, dan metode komparatif. 


\section{DISKUSI DAN HASIL}

Kawasan wisata Pantai Gesing adalah kawasan wisata yang terlekak Desa Girikarto, Kecamatan Panggang, Kabupaten Gunungkidul. Kawasan wisata Pantai Gesing sudh termasuk kedalam RPJMD Kab. Gunungkidul tahun 2016-2021 sebagai kawasan wisata, namun kawasan wisata Pantai Gesing belum memiliki batas kawasan resmi dan belum terdapat rencana penataan sehingga batasan luas perencanaan diasumsikan seluas $\pm 6.96 \mathrm{Ha}$. Kawasan wisata Pantai Gesing masih membutuhkan penambahan fasilitas serta sarana dan prasarana.

Kawasan wisata Pantai Gesing baru diresmikan oleh Dinas Pariwisata (2017) sehingga data mengenai jumlah pengunjung hanya terdapat pada tahun 2017 hingga tahun 2020 sedangkan untuk tahun dibawah tahun 2017 merupakan data yang kurang valid. Berikut merupakan jumlah pengunjung pada tahun 2020 :

Tabel 1. Jumlah Pengunjung Pantai Gesing

\begin{tabular}{cc}
\hline Hari/Tanggal & Jumlah Pengujung \\
\hline $31 / 12 / 2019$ & 3,146 \\
\hline $31 / 01 / 2020$ & 6,393 \\
\hline $28 / 02 / 2020$ & 3,130 \\
\hline $30 / 03 / 2020$ & 2,255 \\
\hline $15 / 04 / 2020$ & 5,470 \\
\hline $24 / 07 / 2020$ & 1,231 \\
\hline $31 / 08 / 2020$ & 4,569 \\
\hline $29 / 09 / 2020$ & 1,252 \\
\hline $29 / 11 / 2020$ & 2,896 \\
\hline $02 / 12 / 2020$ & 2,661 \\
\hline
\end{tabular}

Sumber : Hasil Olahan Penulis, 2021
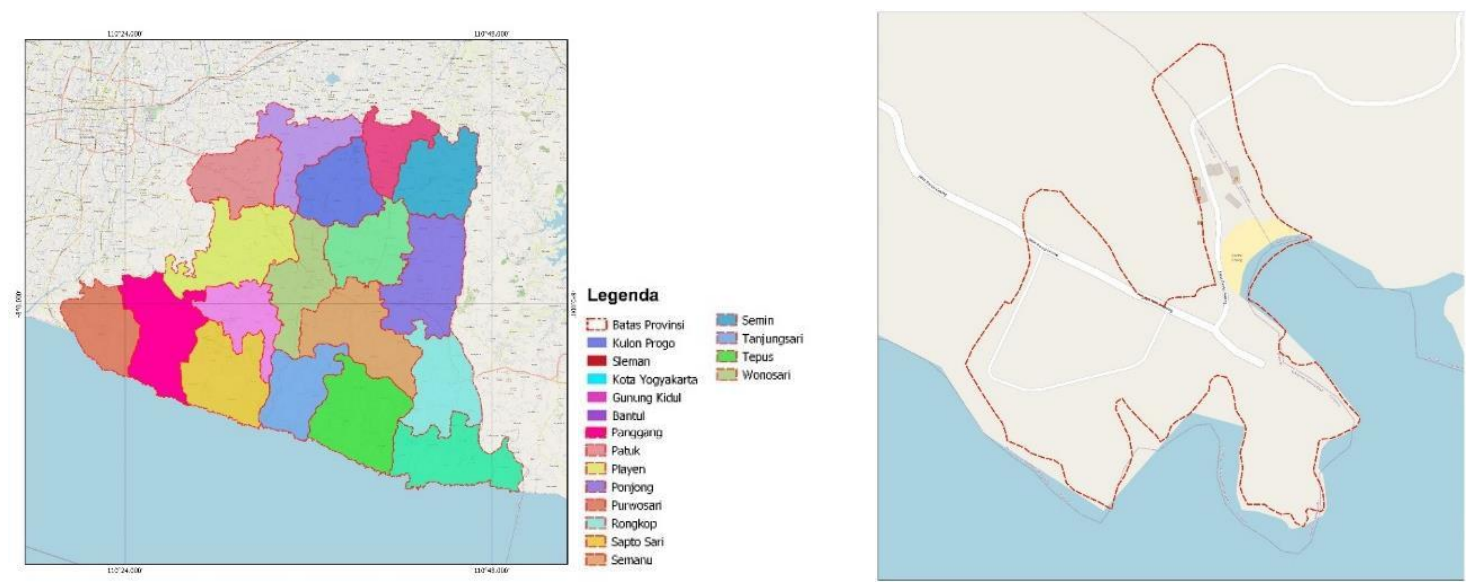

Gambar 1. Peta Batas Kawasan Wisata Pantai Gesing

Sumber : Hasil Olahan Penulis, 2021 


\section{Analisis Lokasi}

Kawasan wisata Pantai Gesing dapat diakses dengan mudah karena lokasinya dapat diakses melalui jalur darat, stasiun kereta api dan jalur udara. Pengunjung dapat menggunakan kendaraan pribadi jika melalui jalur darat, dapat melalui Stasiun Yogyakarta, Stasiun Lempuyangan serta dapat melalui Bandar Udara Adisucipto dan Bandara International Yogyakarta (YIA). Namun, belum tersedia transportasi umum untuk menuju Kawasan wisata Pantai Gesing sehingga hanya dapat menggunakan kendaraan pribadi, ojek online ataupun taksi online. Kawasan wisata Pantai Gesing memiliki keterdekatan dengan fasilitas-fasilitas yang berada dalam radius $5 \mathrm{~km}$ dan $10 \mathrm{~km}$, berikut merupakan table keterdekatannya :

Tabel 2. Proximity Kawasan Wisata Pantai Gesing

\begin{tabular}{|c|c|c|}
\hline \multirow{2}{*}{ lenis } & \multicolumn{2}{|c|}{ Radius } \\
\hline & $5 \mathrm{~km}$ & $10 \mathrm{~km}$ \\
\hline Fasilitas Kesehatan & $\underline{0}$ & $\underline{4}$ \\
\hline Fasilitas Akomodasi & $\underline{2}$ & $\underline{8}$ \\
\hline Perdagangan & $\underline{1}$ & $\underline{4}$ \\
\hline Objek Wisata & $\underline{4}$ & $\underline{5}$ \\
\hline \multirow{2}{*}{ Total } & 7 & 21 \\
\hline & \multicolumn{2}{|c|}{28} \\
\hline
\end{tabular}

Sumber : Hasil Olahan Penulis,2021

Di sekitar wisata Pantai Gesing terdapat juga objek wisata yang berupa wisata pantai dan juga wisata rekreasi. Terdapat objek wisata yang berdekatan dengan wisata Pantai Gesing dan dapat ditempuh selama 2 menit dengan menggunakan kendaraan pribadi. Berikut merupakan table objek wisata yang terdekat dengan kawsana wisata Pantai Gesing :

Tabel 3. Proximity Pantai Gesing terhadap Objek Wisata

\begin{tabular}{llcc}
\hline \multirow{2}{*}{ Objek Penelitian } & \multicolumn{1}{c}{ Objek Wisata } & Jarak Tempuh & Waktu Tempuh \\
& Teras Kaca & $900 \mathrm{~m}$ & 2 Menit \\
\cline { 2 - 4 } Pantai Gesing & Pantai Kukup & $31 \mathrm{~km}$ & 51 Menit \\
\cline { 2 - 4 } & Pantai Baron & $30.3 \mathrm{~km}$ & 49 Menit \\
\cline { 2 - 4 } & Pantai Ngobaran & $26.3 \mathrm{~km}$ & 50 Menit \\
\cline { 2 - 4 } & Tanjung Kesirat & $9.6 \mathrm{~km}$ & 20 Menit \\
\hline & Pantai Wohkudu & $5.6 \mathrm{~km}$ & 22 Menit \\
& Pantai Ngrenehan & $26.7 \mathrm{~km}$ & 49 Menit \\
\cline { 2 - 4 } & Pantai Ngunggah & $14.7 \mathrm{~km}$ & 41 Menit \\
\cline { 2 - 4 } & Pantai Ngrumpon & $19.8 \mathrm{~km}$ & 49 Menit \\
\hline
\end{tabular}

Sumber : Hasil Olahan Penulis,2021 

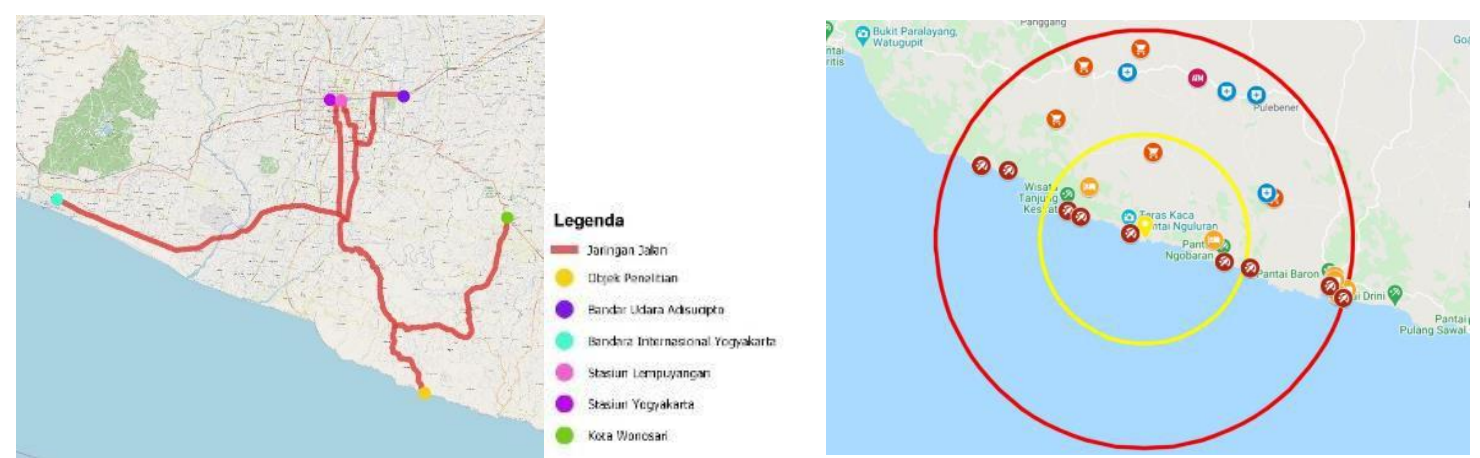

Gambar 2. Peta Aksesibilitas (kiri) dan Peta Proximity (kanan)

Sumber : Hasil Olahan Penulis, 2021

\section{Analisis Daya Tarik}

Menurut Yoeti (1996:177) suatu objek wisata atau daya tarik wisata dapat menarik dikunjungi bila memenuhi beberapa syarat yaitu something to see, something to do, dan something to buy.

\section{Something To See}

Kawasan wisata Pantai Gesing memiliki keindahan alam yang semakin indah jika diliat diatas bukit, selain itu kawasan Wisata Pantai Gesing memilik ombak yang kecil sehingga menjadi keunikan untuk kawasan wisata Pantai Gesing yang berbeda dari pantai selatan lainnya. Kawsan wisata Pantai Gesing juga memiliki pasir pantai yang halus dan berwarna krem muda dan laut yang berwarna biru. Ombak kecil di pantai ini bisa digunakan untuk bermain air yang aman bagi orang dewasa juga anak kecil. Pantai Gesing memiliki spot foto terkenal bernama jembatan cinta yang terletak diatas bukit sehingga cukup banyak pengunjung yang dating karena jembatan cinta ini.

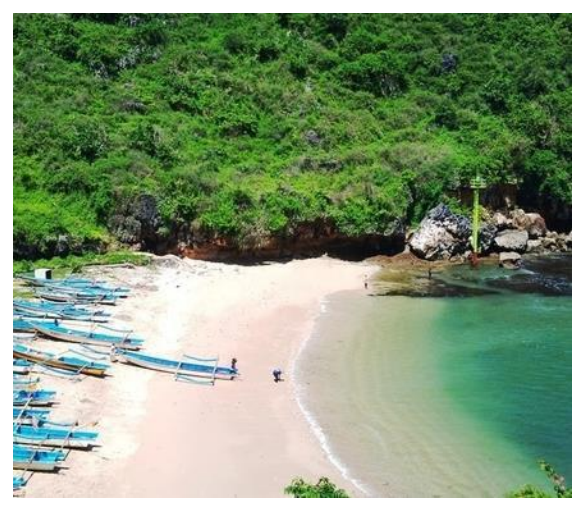

Gambar 3. Keindahan Alam (k

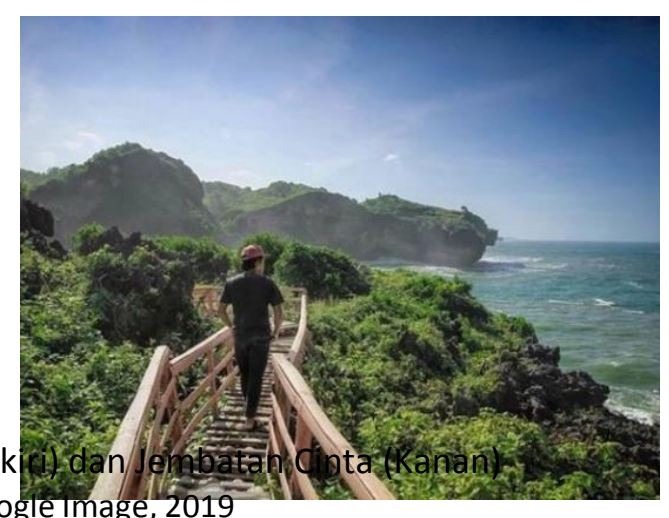

\section{Something To Do}

Kawasan wisata Pantai Gesing kawasan wisata yang banyak memanfaatkan keadaan alam di sekitarnya sehingga terdapat berbagai macam kegiatan yang dapat dilakukan di kawasan wisata Pantai Gesing yaitu menikmati keindahan alam, bermain air, photoshoot, memancing, menikmati kuliner hasil laut, berkeliling menggunakan perahu nelayan, menikmati pemandangan sunset dan berkemah. 

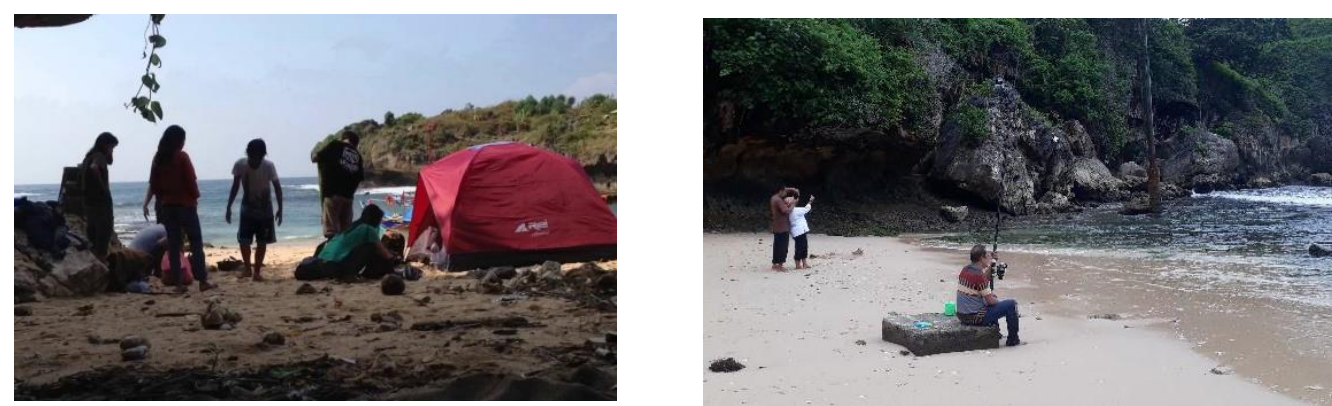

Gambar 4. Kegiatan Wisata Pantai Gesing

Sumber : Dokumentasi Penulis dan Google Image, 2021

\section{Something To Buy}

Kawasan Wisata Pantai Gesing belum memiliki kios-kios souvenir yang menjadi oleh-oleh khas sehingga pengunjung hanya bisa membeli kuliner hasil laut yang dijual di rumah makan jika pengunjung ingin membawa ikan segar maka pengunjung bisa membeli langsung dari nelayan atau dapat mengukuti kegiatan lelang di TPI yang telah disediakan.

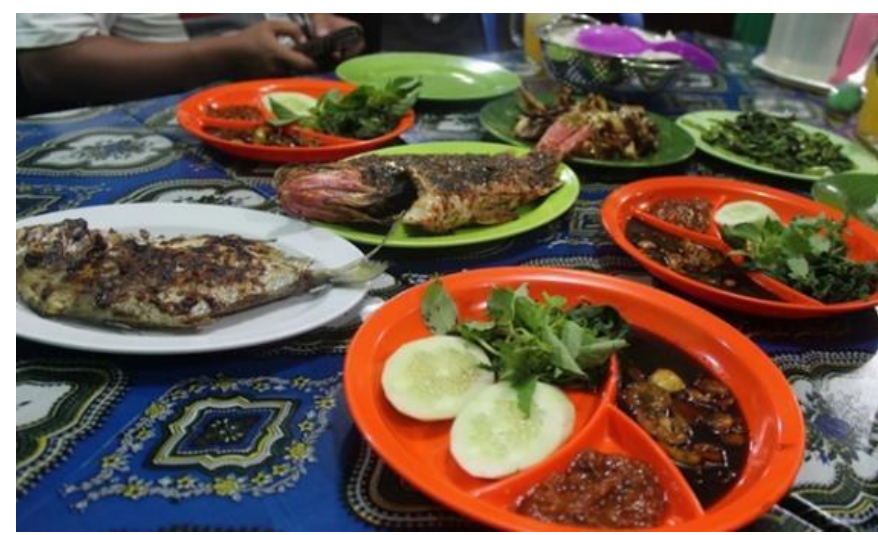

Gambar 5. Kuliner Hasil Laut Pantai Gesing Sumber : Google Image, 2018

\section{Analisis Persepsi dan Preferensi}

Analisis persepsi dilakukan menggunakan metode IPA (Importance Performance Analysis) dan CSI (Customer Satisfaction Index) yang dihitung dengan menggunakan skala likert. Hasil yang didapatkan dari penyebaran kueisoner pada wisatawan kawasan wisata Pantai Gesing berdasarkan hasil perhitungan CSI, mendapatkan nilai kepuasan responden sebesar $47.15 \%$ yang menyatakan bahwa responden sebagai sampel wisatawan Kawasa wisata Pantai Gesing merasa kurang puas dengan faktor-faktor kepuasan wisatawan yang terdapat pada kuesioner yang disebarkan.

Hasil usulan wisatawan didapatkan dari penyebaran kuesioner terkait dengan kegiatan wisata dan fasilitas yang perlu ditambahkan pada objek wisata. Kegiatan wisata yang perlu ditambahkan berdasarkan hasil kuesioner yang diisi maka didapatkan sebanyak 10 responden yang memilih untuk penambahan kegiatan wisata berkeliling dengan perahu sedangkan sarana prasarana yang perlu ditambahkan adalah penyediaan jaringan telekomunikasi yang dipilih oleh 34 responden. 


\section{Analisis Best Practive}

Best practive yang dipilih akan terdapat 3 best practive dengan masing masing jenis wisata yang telah sesuai dengan kondisi eksisting dan tambahan improvisasi dari penulis yang cukup serupa dengan keadaan yang ada pada tapak. Untuk Tempat Pelelangan Ikan Pantai Gesing, Pasar ikan Muara Baru, dan Pasar Ikan Toyosu, Jepang akan dimasukan ke dalam zona wisata kuliner yang sesuai dengan salah satu kegiatan yang terdapat di kawasan wisata Pantai Gesing.

Tabel 4. Aktifitas dan Fasilitas Wisata Benchmarking

\begin{tabular}{|c|c|c|c|c|c|}
\hline $\begin{array}{c}\text { Nama } \\
\text { Kawasan } \\
\text { Wisata }\end{array}$ & Lokasi & Aksesibilitas & Kegiatan Wisata & $\begin{array}{c}\text { Infrastruktur, Fasilitas } \\
\text { Umum dan Fasilitas } \\
\text { Pariwisata }\end{array}$ & Wisatawan \\
\hline $\begin{array}{l}\text { Pasar ikan } \\
\text { Muara } \\
\text { Baru }\end{array}$ & $\begin{array}{l}\text { Jl. Muara Baru } \\
\text { No.21, RW.17, } \\
\text { Penjaringan, Kec. } \\
\text { Penjaringan, } \\
\text { Jakarta Utara }\end{array}$ & $\begin{array}{l}\text { Dapat ditempuh } \\
\text { dengan } \\
\text { menggunakan Bis } \\
\text { dari halte } 12 \mathrm{~A}, 1 \mathrm{~A}, \\
\text { P02, dan U11 }\end{array}$ & $\begin{array}{l}\text { 1. Pelelangan Ikan, } \\
\text { 2. Menjual Hasil } \\
\text { Olahan Laut }\end{array}$ & $\begin{array}{l}\text { 1. } \text { Toilet } \\
\text { 2. } 894 \text { Lapak basah } \\
\text { 3. } 155 \text { lapak kering } \\
\text { 4. } 155 \text { unit maritime } \\
\text { 5. } 2 \text { unit mesin ice } \\
\text { flake } \\
\text { 6. food court } \\
\text { 7. Area pemasaran } \\
\text { 8. Ruang pendingin } \\
\text { 9. Tempt bongkar } \\
\text { muat } \\
\text { 10. Instalasi } \\
\text { pengolahan air } \\
\text { limbah } \\
\end{array}$ & $\begin{array}{l}\text { Wisatawan } \\
\text { Lokal dan } \\
\text { Mancanegara }\end{array}$ \\
\hline $\begin{array}{l}\text { Pasar Ikan } \\
\text { Toyosu, } \\
\text { Jepang }\end{array}$ & $\begin{array}{l}6 \text { Chome-6-1 } \\
\text { Toyosu, Koto City, } \\
\text { Tokyo 135-0061, } \\
\text { Jepang }\end{array}$ & $\begin{array}{l}\text { Dapat ditempuh } \\
\text { dengan } \\
\text { menggunakan kereta } \\
\text { Yurikakome line dan } \\
\text { berhenti di stasiun } \\
\text { Shijo Mae dengan } \\
\text { perjalanan sekitar } 25 \\
\text { menit dan biaya } \\
\text { sebesar } 380 \text { Yen }\end{array}$ & $\begin{array}{l}\text { 1. Pelelangan Ikan } \\
\text { 2. Menjual olahan } \\
\text { Seafood secara } \\
\text { Grosir } \\
\text { 3. Pusat grosir buah } \\
\text { dan sayuran } \\
\text { 4. Menonton } \\
\text { kegiatan } \\
\text { pelelangan }\end{array}$ & $\begin{array}{ll}\text { 1. } & \text { Area khusus } \\
\text { pelelangan } \\
\text { 2. Restorant } \\
\text { 3. Rooftop Garden } \\
\text { untuk melihat Pantai } \\
\text { Teluk Tokyo } \\
\text { 4. Toilet } \\
\text { 5. Ruang pendingin }\end{array}$ & $\begin{array}{l}\text { Wisatawan } \\
\text { Lokal dan } \\
\text { Mancanegara }\end{array}$ \\
\hline $\begin{array}{l}\text { Sydney } \\
\text { Fish } \\
\text { Market, } \\
\text { Australia }\end{array}$ & $\begin{array}{l}\text { Corner Pyrmont } \\
\text { Bridge Rd \&, Bank } \\
\text { St, Pyrmont NSW } \\
\text { 2009, Australia }\end{array}$ & $\begin{array}{l}\text { Dapat ditempuh } \\
\text { menggunakan light } \\
\text { rail dari stasiun } \\
\text { central Paddy's } \\
\text { Market atau Darling } \\
\text { Harbour kemudian } \\
\text { berhenti di halte } \\
\text { Sydney Fish Market }\end{array}$ & $\begin{array}{l}\text { 1. Pelelangan Ikan, } \\
\text { Menjual olahan } \\
\text { Seafood } \\
\text { 2. Tur seputar } \\
\text { pelelangan }\end{array}$ & $\begin{array}{l}\text { 1. Area khusus } \\
\text { pelelangan, } \\
\text { 2. Foodcourt, } \\
\text { 3. toilet, } \\
\text { 4. Ruang pendingin, } \\
\text { 5. Ruang quality } \\
\text { control }\end{array}$ & $\begin{array}{l}\text { Wisatawan } \\
\text { Lokal dan } \\
\text { Mancanegara }\end{array}$ \\
\hline
\end{tabular}

Sumber : Hasil Olahan Penulis, 2021

Masterplan Kawasan Wisata Pantai GSesing

Penataan kawasan wisata Pantai Gesing akan dibagi menjadi 4 zona perencanaan, yaitu zona inti, zona peggembangan, zona penyangga dan zona pelayanan dengan kebutuhan ruang sebagai berikut :

Table 5. Rencana Kebutuhan Ruang

\begin{tabular}{clccc}
\hline \multirow{2}{*}{ Zona } & \multirow{2}{*}{ Fasilitas } & \multicolumn{2}{c}{ Luas } & \multirow{2}{*}{ Sumber } \\
\cline { 3 - 4 } & & $\mathrm{m} 2$ & $\mathrm{Ha}$ & \\
\hline \multirow{2}{*}{ Inti } & TPI & 3250 & 0,325 & Asumsi Penulis \\
\cline { 2 - 4 } & Ruang Penunjang TPI & 250 & 0,025 & Asumsi Penulis \\
\hline
\end{tabular}




\begin{tabular}{|c|c|c|c|c|}
\hline & Menara Pandang & 70 & 0,007 & Kementrian Pariwisata \\
\hline \multicolumn{2}{|c|}{ Kebutuhan Zona Inti } & 3570 & 0,357 & \\
\hline \multirow[t]{5}{*}{ Penyangga } & Area Parkir & 328 & 0,033 & Kementrian Pariwisata \\
\hline & Mushola & 164 & 0,016 & $\mathrm{SNI}$ \\
\hline & Toilet & 141 & 0,014 & Standart Arsitektur Ernst Neufert \\
\hline & Ruang Ganti & 123 & 0,012 & Standart Arsitektur Ernst Neufert \\
\hline & Wahana & 1500 & 0,15 & Asumsi Penulis \\
\hline \multicolumn{2}{|c|}{ Kebutuhan Zona Penyangga } & 2256 & 0,225 & \\
\hline \multirow[t]{4}{*}{ Pengembangan } & Pusat Informasi & 112 & 0,011 & Kementrian Pariwisata \\
\hline & Wahana & 1500 & 0,150 & Asumsi Penulis \\
\hline & Gazebo & 100 & 0,01 & Standart Arsitektur Ernst Neufert \\
\hline & ATM & 10 & 0,001 & Asumsi Penulis \\
\hline \multicolumn{2}{|c|}{ Kebutuhan Zona Pengembangan } & 1722 & 0,172 & \\
\hline \multirow[t]{9}{*}{ Pelayanan } & Guesthouse & 3000 & 0,300 & Asumsi Penulis \\
\hline & Glamping Area & 1500 & 0,150 & Asumsi Penulis \\
\hline & Kios souvenir & 3924 & 0,392 & Kementrian Pariwisata \\
\hline & Rumah Makan & 1605 & 0,161 & Kementrian Pariwisata \\
\hline & Gazebo & 100 & 0,010 & Standart Arsitektur Ernst Neufert \\
\hline & Area Parkir & 1942 & 0,194 & Kementrian Pariwisata \\
\hline & Toilet & 141 & 0,014 & Standart Arsitektur Ernst Neufert \\
\hline & Pusat Informasi & 112 & 0,011 & Kementrian Pariwisata \\
\hline & ATM & 10 & 0,001 & Asumsi Penulis \\
\hline \multicolumn{2}{|c|}{ Kebutuhan zona pelayanan } & 12334 & 1,233 & \\
\hline \multicolumn{2}{|c|}{ Total kebutuhan ruang } & 19882 & 1,988 & \\
\hline \multicolumn{2}{|c|}{ Presentase kebutuhan ruang } & & $29 \%$ & \\
\hline
\end{tabular}

Sumber: Hasil Olahan Penulis, 2021

Rencana penggunaan lahan yang akan dilakukan di Kawasan Wisata Pantai Gesing akan disesuaikan dengan keadaan karakteristik yang ada di Kawasan Wisata Pantai Gesing dan tetep mempertahankan kualitas alam pada area Pantai Gesing dengan rencana sebagai berikut :

Tabel 6. Rencana Penggunaan Lahan Wisata Pantai Gesing

\begin{tabular}{|c|l|c|c|}
\hline No & Jenis Penggunaan Lahan & Luas (Ha) & Presentase (\%) \\
\hline $\mathbf{1}$ & Fasilitas & 0,010 & \\
\hline & Gazebo & 0,025 & \\
\hline & Ruang Pendukung TPI & 0,007 & \\
\hline & Menara Pandang & 0,011 & \\
\hline & Pusat Informasi & 0,033 & \\
\hline & Area Parkir & 0,014 & \\
\hline & Toilet dan Ruang Ganti & 0,001 & \\
\hline & ATM & 0,016 & \\
\hline & Mushola & $\mathbf{0 , 0 9 2}$ & \\
\hline $\mathbf{2}$ & Total Luas Fasilitas & & \\
\hline & Komersil & 0,325 & \\
\hline & TPI & 0,161 & \\
\hline
\end{tabular}




\begin{tabular}{|c|l|c|r|}
\hline No & Jenis Penggunaan Lahan & Luas (Ha) & Presentase (\%) \\
\hline & Kios Souvenir & 0,392 & \\
\hline & Wahana Bermain & 0,150 & $\mathbf{1 5 \%}$ \\
\hline $\mathbf{3}$ & Total Luas Komersil & $\mathbf{1 , 0 5 3}$ & \\
\hline & Penginapan & \multicolumn{2}{|c|}{} \\
\hline & Guesthouse & 0,300 & $\mathbf{7 7 \%}$ \\
\hline & Glamping Area & 0,150 & $\mathbf{1 0 0 \%}$ \\
\hline $\mathbf{4}$ & Total Luas Penginapan & $\mathbf{0 , 4 5 0}$ & $\mathbf{5 , 3 5 9}$ \\
\hline & Hutan & $\mathbf{6 , 9 5 4}$ & \\
\hline \multicolumn{2}{|c|}{ Total }
\end{tabular}

Sumber : Hasil Olahan Penulis, 2021

Konsep penataan yang akan diterapkan di Kawasan Wisata Pantai Gesing yaitu konsep wisata kuliner dan kawan wisata rekreasi. Pemilahan konsep wisata ini berdasarkan kondisi eksisting yang berada di Kawasan Wisata Pantai Gesing. Pemilihan konsep wisata kuliner didasari oleh kegiatan penduduk di kawasan wisata Pantai Gesing yang banyak bekerja sebagai nelayan, selain itu terdapatnya tempat pelelangan ikan dan hasil laut yang beragam bisa dapat dijual dan dapat dikembangkan juga paket wisata yang berbasis kuliner. Pemilihan konsep wisata rekreasi didasari oleh keunikan dan pemandangan alam yang dimiliki oleh kawasan wisata Pantai Gesing dengan memperbaiki spot foto serta menambah spot foto baru, wahana bermain, dan menampilkan kebudayaan penduduk di kawasan wisata ini. Pemilihan konsep ini dipilih agar dapat bermanfaat bagi warga lokal dengan mengembangka kawasan wisata ini bersama serta dapat memberikan dampak positif bagi ekonomi, sosial dan peningkatan kualitas hidup. Pemilihan konsep ini juga agar dapat menjadi kepuasan bagi pengunjung yang di dapat dengan melakukan tata kelola wisata yang baik, dapat memberikan daya tarik alami, yang mampu memberikan jaminan kemanan, kenyamanan dan keselamatan bagi wisatawan, serta didukung pelayanan yang prima.

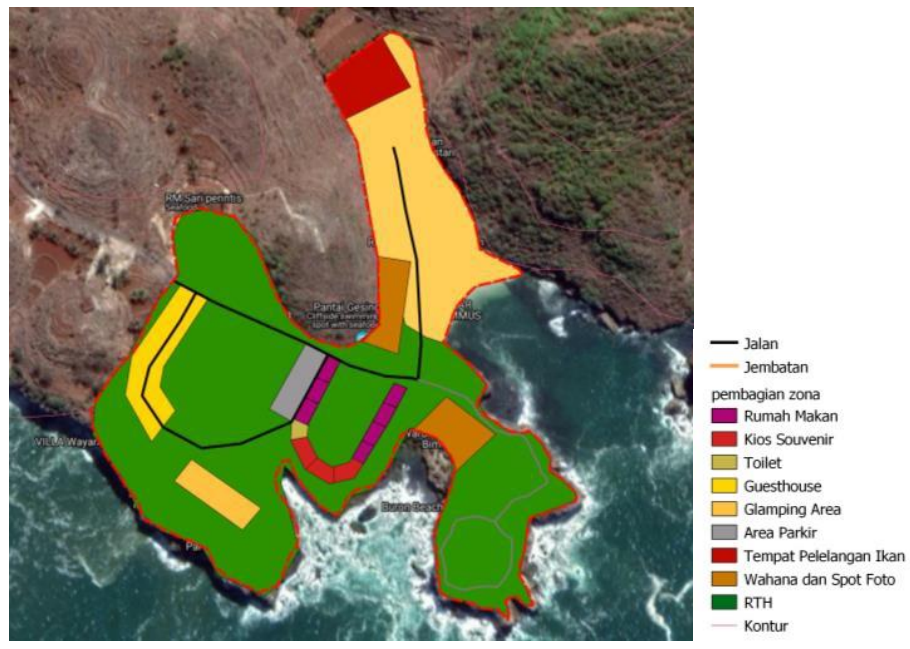

Gambar 6. Masterplan Kawasan Wisata Pantai Gesing Sumber : Hasil Olahan Penulis,2021

\section{KESIMPULAN DAN SARAN}

Berdasarkan penelitian ini maka penulis mendapat beberapa kesimpulan berdasarkan hasil penelitian sebagai berikut: 
1. Kawasan wisata Pantai Gesing telah menjadi kawasan wisata resmi di Kabupten Gunungkidul namun kawasan wisata Pantai Gesing masih belum memiliki batas kawasan yang resmi serta belum adanya rencana promosi sehingga sehingga kawasan wisata Pantai Gesing kurang dikenal dan juga disebabkan oleh minimnya informasi yang dibagikan ke public

2. Berdasarkan pendekatan observasi, benchmarking, dan survey sekunder maka beberapa daya tarik yang terdapat pada kawasan wisata Pantai Gesing adalah sebagai berikut :

a. Kawasan wisata Pantai Gesing memiliki keunikan pada ombak dan pasir pantainya yang dapat dimanfaatkan untuk dimasukan kedalam rencana promosi serta dapat meningkatkan kualitas kebersihan air laut dan pasir pantainya

b. Kawasan wisata Pantai Gesing yang memiliki beragam hasil laut dapat jadikan sebagai salah satu kegiatan untuk dipromosikan, dengan beragamnya hasil laut juga dapat mejadi peluang bagi kawasan wisata Pantai Gesing untuk melakukan festival kuliner dari berbagai olahan hasil laut yang dapat dijadikan ciri khas

c. Sebagai tempat rekreasi yang banyak dikunjunging bersama keluarga, pasangan dan juga teman dengan menikmati pemandangan alam dari atas bukit kawasan wisata Pantai Gesing.

3. Dari hasil penelitian yang dilakukan terkait penataan kawasan wisata Pantai Gesing, berikut merupakan beberapa usulan untuk rencana penataan kawasan wisata Panta Gesing untuk meningkatkan daya tarik dan untuk melakukan promosi :

a. Melakukan perbaikan kondisi fasilitas yang telah ada, membangun fasi;itas, sarana dan prasarana seperti guest house, jaringan telekomunikasi dan fasilitaas, sarana dan prasarana lainnya

b. Melakukan kerja sama dengan pihak pokdarwis untuk dapat mempromosikan kebudayaan penduduk sekitar sebagai salah satu ciri khas kawasan wisata ini .

c. Melakukan kerja sama dengan pihak-pihak travel agent untuk dapat memberikan paket usaha yang menarik bagi pengunjung dan bekerja sama untuk melakukan promosi melalui social media

\section{Rekomendasi}

1. Sarana dan Prasrana

Melakukan perawatan sarana dan prasarana umum yang memiliki kondisi baik dan meningkatkan sarana dan prasarana umum yang memiliki kondisi buruk. Selain itu menambah tempat sampah di lingkungan sekitar pantai dan disekitar rumah makan, membangun jaringan telekomunikasi yang dapat memper mudah pengunjung untuk memperoleh informasi, promosi dan komunikasi selama berkunjung di kawasan wisata Pantai Gesing.

2. Daya Tarik

Dalam hal daya tarik, pihak pengelola dapat mengadakan festival kuliner untuk memanfaatkan dengan optimal hasil laut yang telah ada agar dapat menambah ciri khas dari kawasan wisata Pantai Gesing.

3. Promosi

Promosi dapat dilakukan melalui media cetak, iklan, media sosial dan festival atau event yang diadakan. Dinas Pariwisata Kabupaten Gunungkidul dapat melakukan sebagian besar promosi yang secara spesifik membrandingkan kawasan wisata Pantai Gesing, serta dapat 
juga membuaat laman khusus mengenai kawasan wisata pantai Gesing yang menjadi wadah dalam membrandingkan kawasan wisata Pantai Gesing. Pokdarwis juga dapat melakukan promosi dengan memanfaatkan kebudayaan masyarakat serta dapat bersama-sama untuk menghasilkan barang oleh-oleh khas masyarakat.

\section{Saran}

Dalam penelitian yang telah penulis lakukan, penulis ingin memberikan beberapa saran kepada beberapa pihak yang berkaitan dengan Kawasan Wisata Pantai Gesing.

a. Dinas Pariwisata Kabupaten Gunungkidul, sebagai salah satu pengurus kawasan wisata Pantai Gesing untuk dapat menjalin komunikasi dan kerja sama yang baik dengan kelompok sadar wisata (Pokdarwis) Pantai Gesing mengenai perencanaan penataan kawasan wisata Pantai Gesing.

b. Dinas Pariwisata Kabupaten Gunungkidul dapat mengikut sertakan masyarakat sekitar dalam perencanaan penataan kawasan wisata Pantai Gesing

c. Kelompok sadar wisata (Pokdarwis) dapat bekerja sama dalam perencanaan penataan

d. wisata Pantai Gesing, membantu dalam ketertiban dan keamanan para wisata yang berkunjung

e. Masyarakat sekitar dapat membantu dalam menjaga kebersihan lingkungan sekitar kawasan

f. wisata Pantai Gesing serta berjualan ditempat yang telah di tentukan

\section{REFERENSI}

Gani, Y. A. (2017). Pengembangan Sarana Prasarana Destinasi Pariwisata Berbasis Budaya di Jawa Barat. Jurnal Pariwisata , 24-25.

Gunungkidul, P. D. (2016). RPJMD Kabupaten Gunungkidul Tahun 2016 - 2021. Daerah Istimewa Yogyakarta.

Gunungkidul, P. D. (2018). Rencana Pembangunan Kawasan Perdesaan Agropolitan Wisata Alam Minat Khusus dan Wisata Pantai. Daerah Istimewa Yogyakarta.

Indonesia, R. (2019). Undang-undang No.10 Tahun 2009 Tentang Kepariwisataan. Jakarta.

Inskeep, E. (1991). Tourism Planning : An Integrated and Sustainable Development Approach. New York: Van Nostrand Reinhold.

Marpaung, H. (2002). Pengantar Pariwisata. Bandung: Alfabeta.

Suwantoro, G. (2004). Dasar-Dasar Pariwisata. Daerah Istimewa Yogyakarta.

Yoeti, O. (1996). Pengantar Ilmu Pariwisata. Bandung: Angkasa.

Yoeti, O. (2010). Dasar-dasar Pengertian Hospitalyti Pariwisata. Bandung: PT. Alumni.

Yogyakarta, P. D. (2019). Peraturan Daerah Daerah Istimewa Yogyakarta Nomor 1 Tahun 2019 tentang Perubahan atas Peraturan Daerah Istimewa Yogyakarta No,1 Tahun 2012 tentang Rencana Induk Pembangunan Kepariwisataan Daerah Provinsi Daerah Isrimewa Yogyakarta. Daerah Isrimewa Yogyakarta. 
